\title{
Cytotoxic T-Cells in Peripheral Blood in Women with Endometriosis
}

\section{Zytotoxische T-Zellen im peripheren Blut bei Frauen mit Endometriose}

Authors

Affiliations
N. Slabe ${ }^{1}$, H. Meden-Vrtovec ${ }^{1}$, I. Verdenik ${ }^{1}$, R. Kosir-Pogacnik ${ }^{1}$, A. Ihan $^{2}$

${ }^{1}$ Obstetrics and Gynecology, University Clinical Centre Ljubljana, Ljubljana, Slovenia

${ }^{2}$ Institute of Microbiology and Immunology, Faculty of Medicine, Ljubljana, Slovenia

\author{
Key words \\ - endometriosis \\ - gynecology \\ - infertility \\ $\checkmark$ regulatory T cells \\ - cell immunity

\section{Schlüsselwörter} \\ - Endometriose \\ - Gynäkologie \\ - Infertilität \\ - regulatorische T-Zellen \\ - Zell-Immunität
}

\section{received 16.4.2013 \\ revised 3.6.2013 \\ accepted 17.6.2013}

Bibliography

DoI http://dx.doi.org/

10.1055/s-0033-1350702

Geburtsh Frauenheilk 2013; 73 :

1042-1048 c) Georg Thieme

Verlag KG Stuttgart - New York . ISSN 0016-5751

\section{Correspondence}

Dr. Nina Slabe

University Clinical Centre

Ljubljana

Obstetrics and Gynecology

Slajmerjeva 3

1000 Ljubljana

Slovenia

nina.slabe@t-2.net

\section{Abstract \\ $\nabla$}

Aim: The etiology of endometriosis remains unknown, but increasing evidence suggests that immune regulation may be important. Our study aimed to evaluate peripheral blood lymphocyte subpopulations during the menstrual cycle in women with peritoneal and ovarian endometriosis relative to healthy women.

Methods: In this study, 65 women with endometriosis (37 in the follicular phase and 28 in the luteal phase of the menstrual cycle) and 61 healthy women (33 in the follicular phase and 28 in the luteal phase) were enrolled. Flow cytometric analysis measured peripheral blood lymphocyte subpopulations. The serum levels of cortisol were also determined.

Results: In healthy controls, we detected an increased concentration of cytotoxic $\left(\mathrm{CD}^{+}\right) \mathrm{T}$ cells and activated (HLA-DR) $\mathrm{T}$ cells in the luteal phase compared with the follicular phase of the menstrual cycle $(p=0.020$ and $p=0.045)$, whereas no such fluctuation was detected in endometriosis. However, a marked increase in regulatory T-cell concentration in the luteal phase was detected only in endometriosis patients $(p=0.005)$. Women with endometriosis had higher levels of serum cortisol $(p=0.022)$, which correlated with the concentration of regulatory T cells $(\mathrm{p}=0.048)$.

Conclusions: Women with endometriosis do not exhibit fluctuations in the concentrations of cytotoxic and activated peripheral blood lymphocytes during the menstrual cycle. The marked fluctuation of regulatory $\mathrm{T}$ cells detected in endometriosis could be attributed to altered immune response.

\section{Zusammenfassung \\ $\nabla$}

Einleitung: Endometriose ist ein häufiges, jedoch komplexes gynäkologisches Syndrom unbekannter Pathogenese, von dem Frauen im gebärfähigen Alter befallen sind. Die Ätiologie der Endometriose bleibt unbekannt, aber immer häufigere Beweise zeigen, dass das Immunsystem dabei eine große Rolle spielt. Unsere Studie zielte darauf ab, die peripheren Blutlymphozytensubpopulationen während des Menstruationszyklus bei Frauen mit Peritoneal- und Ovarialendometriose im Vergleich zu gesunden Frauen zu bewerten.

Methoden: Die Studie umfasste 65 Frauen mit Endometriose (37 in der Follikelphase und 28 in der Lutealphase des Menstruationszyklus) und 61 gesunde Frauen (33 in der Follikelphase und 28 in der Lutealphase des Menstruationszyklus). Die Lymphozytensubpopulationen wurden mittels Durchflusszytometrie festgestellt. Der Serumspiegel von Cortisol wurde ebenfalls bestimmt.

Ergebnisse: Bei gesunden Probanden fanden wir im peripheren Blut eine erhöhte Konzentration von zytotoxischen $\left(\mathrm{CD}^{+}\right)$T-Zellen und aktivierten (HLA-DR) T-Zellen in der Lutealphase gegenüber der Follikelphase des Menstruationszyklus $(p=0,020$ und $p=0,045)$, während keine solche Schwankung in der Endometriose festgestellt wurde. Ein deutlicher Anstieg der regulatorischen T-Zellen-Konzentration in der Lutealphase wurde nur bei Frauen mit Endometriose ermittelt. Frauen mit Endometriose hatten einen höheren Serumspiegel von Cortisol $(p=0,022)$, der mit der Konzentration von regulatorischen T-Zellen ( $\mathrm{p}=0,048)$ korreliert.

Schlussfolgerung: Frauen mit Endometriose zeigen keine Konzentrationsschwankungen von zytotoxischen und aktivierten Lymphozyten im peripheren Blut während des Menstruationszyklus. In der Endometriose nachgewiesene Schwankungen von regulatorischen T-Zellen können auf veränderte Immunantwort zurückgeführt werden. 


\section{Introduction}

\section{$\nabla$}

Endometriosis is a common gynecological condition that affects $5-15 \%$ of women of reproductive age. It is characterized by the growth and expansion of endometrial-like glands and stroma outside the uterine cavity, most often in the peritoneal cavity and ovaries [1]. The disease process typically involves the surface of the ovaries and pelvic peritoneum. It is a risk factor for specific invasive subtypes of ovarian cancer. However, the steps in malignant transformation of ectopic endometrium still need to be understood [2]. Endometriosis represents an important cause of morbidity and affects quality of life in affected women.

The etiology of endometriosis remains poorly understood, but certain features suggest that immune regulation may be important. Characteristics frequently found in women with endometriosis are multiorgan involvement, familial occurrence, a genetic basis, environmental factors, responsiveness to hormonal therapy, previous tissue damage, polyclonal activation of B lymphocytes, immunological abnormalities in the function of $\mathrm{T}$ and $\mathrm{B}$ lymphocytes, and other associated autoimmune diseases [3-9]. Risk factors often mentioned for endometriosis are menstrual cycle length, duration of menstrual bleeding, number of pregnancies and miscarriages, body mass index and smoking status [10].

It is not known how the immune system recognizes ectopic endometrial lesions. It would be necessary for the immune cells that are responsible for the destruction of ectopic endometrial lesions - natural killer cells, cytotoxic T cells, and macrophages - to be well regulated. This would allow the immune system to destroy only ectopic endometrial cells, and not endometrium within the uterine cavity. The main regulators of this process are regulatory T cells (Treg) [11-17].

The endometrium in the uterine cavity is infiltrated by a number of different immune cells, whose role is to maintain immunological homeostasis within the uterus. Berbic et al. $[18,19]$ showed that Treg populations are altered in the endometrium of women with endometriosis during the luteal phase of the menstrual cycle. The dramatic decline in Treg cells in the endometrium during the late follicular phase of the menstrual cycle - typical for healthy women of childbearing age - is absent in endometriosis. The concentration of Treg cells in the uterus in endometriosis remains elevated throughout the menstrual cycle. This can be attributed to the increased quantity of endometrial antigens and uterine exposure to estrogen, which stimulate proliferation of Treg cells in endometriosis [20].

Though we know how Treg cells fluctuate in the endometrium, there is yet no data addressing Treg concentration changes in women with endometriosis in the peripheral blood (PB). Our study aimed to evaluate peripheral blood lymphocyte subpopulations during the menstrual cycle in women with peritoneal and ovarian endometriosis relative to healthy women in order to find possible connection between endometriosis and altered immune response.

\section{Materials and Methods \\ $\nabla$}

This study was approved by the National Medical Ethics Committee in the Ministry of Health, Republic of Slovenia.

\section{Subjects}

We determine the required sample size according to power analysis [21]. The assumption was that the difference in concentration of Treg cells between luteal and follicular phase in endometriosis patients would be $20 \%$ with common standard deviation, after appropriate normalization. That called for 28 patients in each group. To account for possible difficulties in recruiting patients in different phases of menstrual cycle, we decided to enroll 65 endometriosis patients altogether. A similar number of healthy women were enrolled in a control group.

The study group comprised 65 women with endometriosis admitted to the hospital for laparoscopic operation. Diagnosis was confirmed by a histological sample taken by laparoscopy. The inclusion criterion was peritoneal and ovarian endometriosis. We excluded women with deep rectovaginal endometriosis because of the currently favored etiological hypothesis of coelomic metaplasia and the concept of tissue injury and repair $[1,3,22,23]$. In the control group, we enrolled 61 healthy women at reproductive age who had been admitted to the hospital for laparoscopic sterilization (tubal electrocoagulation).

The exclusion criteria for both groups were the presence of pelvic inflammatory disease, polycystic ovary syndrome, gynecological carcinoma, ovarian cysts of a different etiology than endometriosis, and the use of hormonal treatment in the last 3 months. We excluded 12 women with rectovaginal endometriosis, 3 women where endometriosis was not histologically confirmed and 2 women with dermoid ovarian cyst. All patients were previously informed of the purpose of the research, participated voluntarily, and provided signed, written consent.

All patients completed a self-administered questionnaire regarding their menstrual status, and reproductive, personal, and familial history. Additionally, the history of previous immune diseases, such as Hashimoto thyroiditis, asthma, systemic lupus erythematosus, Sjögren's syndrome, rheumatoid arthritis, and vitiligo was collected from documentation. Women were asked about the clinical features most common in endometriosis, dysmenorrhea, dyspareunia and irregular menstrual cycle.

Peripheral blood samples were collected from January 2009 to December 2010 in the Department of Obstetrics and Gynecology at University Medical Centre Ljubljana from 126 women of reproductive age, both with and without endometriosis. Seventy samples were collected in the follicular phase of the menstrual cycle (37 and 33 from women with and without endometriosis, respectively) and 56 samples were collected in the luteal phase of the menstrual cycle (28 and 28 from women with and without endometriosis, respectively). All samples were taken at late morning hours. Evaluation of the endometrium, ovaries, and phase of menstrual cycle was determined by ultrasound examination (Samsung Medison Europe B.V., Samsung Medison Sonoace X6, Hoofddorp, Netherlands).

\section{Lymphocyte subpopulations analysis}

The types of immune abnormality have been identified with immunological investigations at the cellular level: subtypization of lymphocytes, cytotoxic and Treg cells, and natural killer (NK) cells.

For the analysis, $2 \mathrm{~mL}$ of peripheral venous blood were collected in a vacuum tube that contained an anticoagulant (ethylenediaminetetraacetate [EDTA]). With flow cytometry (Becton Dickinson FACS), the concentration of lymphocyte subpopulations was determined: B-lymphocytes $\left(\mathrm{CD} 19^{+}\right)$, T-lymphocytes $\left(\mathrm{CD}^{+}\right)$, Thelper cells $\left(\mathrm{CD}^{+}\right)$, cytotoxic T-lymphocytes $\left(\mathrm{CD}^{+}\right)$, NK cells 
$\left(\mathrm{CD} 6^{+} / \mathrm{CD} 16^{+}\right)$, and regulatory T lymphocytes $\left(\mathrm{CD}^{+} / \mathrm{CD}^{2} 5^{++}\right)$. All monoclonal antibodies were purchased from Becton and Dickinson, USA. Differential leukocyte counts were determined using hematology analyzers (Coulter GEN-S).

\section{Cortisol levels}

Cortisol was quantified in the serum of all subjects using chemiluminescence on an automatic analyzer (Immulite $2000 \mathrm{XPi}$, Siemens), using commercially available kits (Cortisol Immulite 2000). The reference range for cortisol in serum in the morning ranges from $138-690 \mathrm{nmol} / \mathrm{L}$.

\section{Statistical analysis}

Statistical analysis was performed using IBM SPSS software (version 19.0, USA). The distribution of the data was checked for normality using a normal probability plot. Abnormally distributed parameters were normalized or nonparametric tests were applied. Dichotomous variables between groups were compared with the chi-square test. For continuous variables, differences were determined by 2-tailed unpaired t-test or Mann-Whitney test. To analyze the effect of menstrual cycle phase and taking into account other influential variables, analysis of variance was used. The phases and subpopulations were analyzed using descriptive statistics. Pearson's correlation was used to analyze correlations between the levels of cortisol and lymphocyte subpopulations. The characteristics of cases and controls are presented as means and standard deviations or counts and percentages. The differences between groups were considered to be statistically significant for $\mathrm{p}<0.05$.

\section{Results \\ $\nabla$}

The differences between groups are shown in Table 1 .

Enrolled women were 20-46 years old; the mean age in endometriosis patients (study group) was $32.86 \pm 6.09$ years and in the control group, $40.49 \pm 3.96$ years $(p<0.001)$. By law, Slovenian women can opt for sterilization at age 35 year or older. The impact of age on lymphocyte subpopulations is shown in $\bullet$ Table 2.

\section{Lymphocyte subpopulations in the follicular \\ and luteal phase of the menstrual cycle \\ in women with and without endometriosis}

PB lymphocyte subpopulations are different in the follicular and luteal phases of the menstrual cycle. In healthy subjects, we detected a statistically significant increase in the concentration of cytotoxic $\left(\mathrm{CD}^{+}\right) \mathrm{T}$ cells and activated (HLA-DR) T cells in the luteal phase compared with the follicular phase of the menstrual cycle ( $p=0.020$ and $p=0.045)$, whereas no such fluctuation of cytotoxic and activated T cells was detected in endometriosis. However, a significant increase of Treg cells in the luteal phase relative to the follicular phase was detected in endometriosis patients $(\mathrm{p}=0.005)$. The $\mathrm{CD}^{+} / \mathrm{CD}^{+}$ratio was higher in control subjects in the follicular phase $(p=0.008)$. There is an increase in the concentration of $\mathrm{CD}^{+}$cells during the luteal phase in control subjects $(\mathrm{p}=0.020)$ and no differences in the concentration of $\mathrm{CD}^{+}$ cells were detected among groups or phases. We did not detect luteal- or follicular-phase fluctuation in any other PB lymphocyte

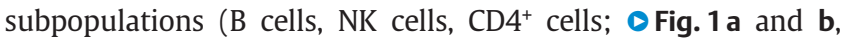
Fig. $2 \mathbf{a}$ and $\mathbf{b}$ ).

The PB concentration of Treg cells in the control group did not fluctuate during the menstrual cycle, whereas in women with
Table 1 Differences between women with endometriosis (study group) and without endometriosis (control group). Data are presented as means \pm standard deviation or counts and percentages.

\begin{tabular}{|lllr|}
\hline & $\begin{array}{l}\text { Study group } \\
\mathbf{n = 6 5}\end{array}$ & $\begin{array}{l}\text { Control group } \\
\mathbf{n = 6 1}\end{array}$ & p-value* \\
\hline Age (years) & $32.86 \pm 6.09$ & $40.49 \pm 3.96$ & $<0.001$ \\
\hline Follicular phase & $37(56.9 \%)$ & $33(54.1 \%)$ & 0.750 \\
\hline Luteal phase & $28(43.1 \%)$ & $28(45.9 \%)$ & 0.750 \\
\hline Dysmenorrhea & $45(69.2 \%)$ & $4(6.6 \%)$ & $<0.001$ \\
\hline Dyspareunia & $23(35.4 \%)$ & $2(3.3 \%)$ & $<0.001$ \\
\hline $\begin{array}{l}\text { Irregular menstrual } \\
\text { cycle }\end{array}$ & $22(33.8 \%)$ & $7(11.5 \%)$ & 0.003 \\
\hline $\begin{array}{l}\text { Associated immune } \\
\text { disease }\end{array}$ & $27(41.5 \%)$ & $23(37.7 \%)$ & 0.660 \\
\hline Cortisol $(\mathrm{nmol} / \mathrm{L})$ & $417 \pm 202$ & $341 \pm 165$ & 0.022 \\
\hline
\end{tabular}

* p-value was judged by Mann-Whitney or unpaired t-test

endometriosis, we detected a significant increase in the luteal phase relative to the follicular phase ( $p=0.005$; $\odot$ Fig. 3 ). The increase of Treg cells in study group relative to controls was statistically significant in luteal phase of menstrual cycle $(p=0.030$; - Fig. 2b).

\section{Serum cortisol levels and peripheral blood lymphocyte} subpopulations

Women with endometriosis had higher serum cortisol levels $(417 \pm 202 \mathrm{nmol} / \mathrm{L}) \quad$ compared with control subjects (341 $\pm 165 \mathrm{nmol} / \mathrm{L} ; \mathrm{p}=0.022$ ). Higher serum cortisol correlated with changes in Treg cells in women with endometriosis ( $\mathrm{p}=0.048$; $\odot$ Table 3$)$.

\section{Discussion}

$\nabla$

The difference in age between study group and controls was statistically significant. By law, Slovenian women can opt for sterilization at age 35 year or older. All women enrolled in our study were at reproductive age. The analysis of variance showed there is no impact of age on lymphocyte subpopulations. Concentration and function of lymphocyte subpopulations are altered significantly with aging and contribute to the aging-related decline of immune responses and lead to the higher risk of immune-mediated diseases in aged individuals [24-26].

Table 2 Impact of age on lymphocyte subpopulations. Lymphocyte subpopulations: $T$ lymphocytes $\left(\mathrm{CD}^{+}\right)$; B lymphocytes $\left(C D 19^{+}\right)$; $T$ helper cells $\left(\mathrm{CD} 4^{+}\right)$; cytotoxic $\mathrm{T}$ lymphocytes $\left(\mathrm{CD} 8^{+}\right)$; natural killer cells (NK); regulatory $\mathrm{T}$ lymphocytes $\left(\mathrm{CD}^{+} / \mathrm{CD}^{2} 5^{++}\right)$; activated T cells (HLA-DR).

\begin{tabular}{|l|l|}
\hline Lymphocyte subpopulations & $\begin{array}{l}\text { Impact of age } \\
\text { p-value* }\end{array}$ \\
\hline $\mathrm{CD}^{+}$ & 0.474 \\
\hline $\mathrm{CD}^{+} 9^{+}$ & 0.308 \\
\hline $\mathrm{CD} 4^{+}$ & 0.265 \\
\hline $\mathrm{CD}{ }^{+}$ & 0.715 \\
\hline $\mathrm{CD} 4 / 8$ & 0.072 \\
\hline $\mathrm{NK}$ & 0.060 \\
\hline $\mathrm{CD} 3^{+} / \mathrm{CD} 25^{++}$ & 0.448 \\
\hline $\mathrm{HLA}-\mathrm{DR}$ & 0.327 \\
\hline
\end{tabular}

* p-value was judged by analysis of variance (ANOVA) 

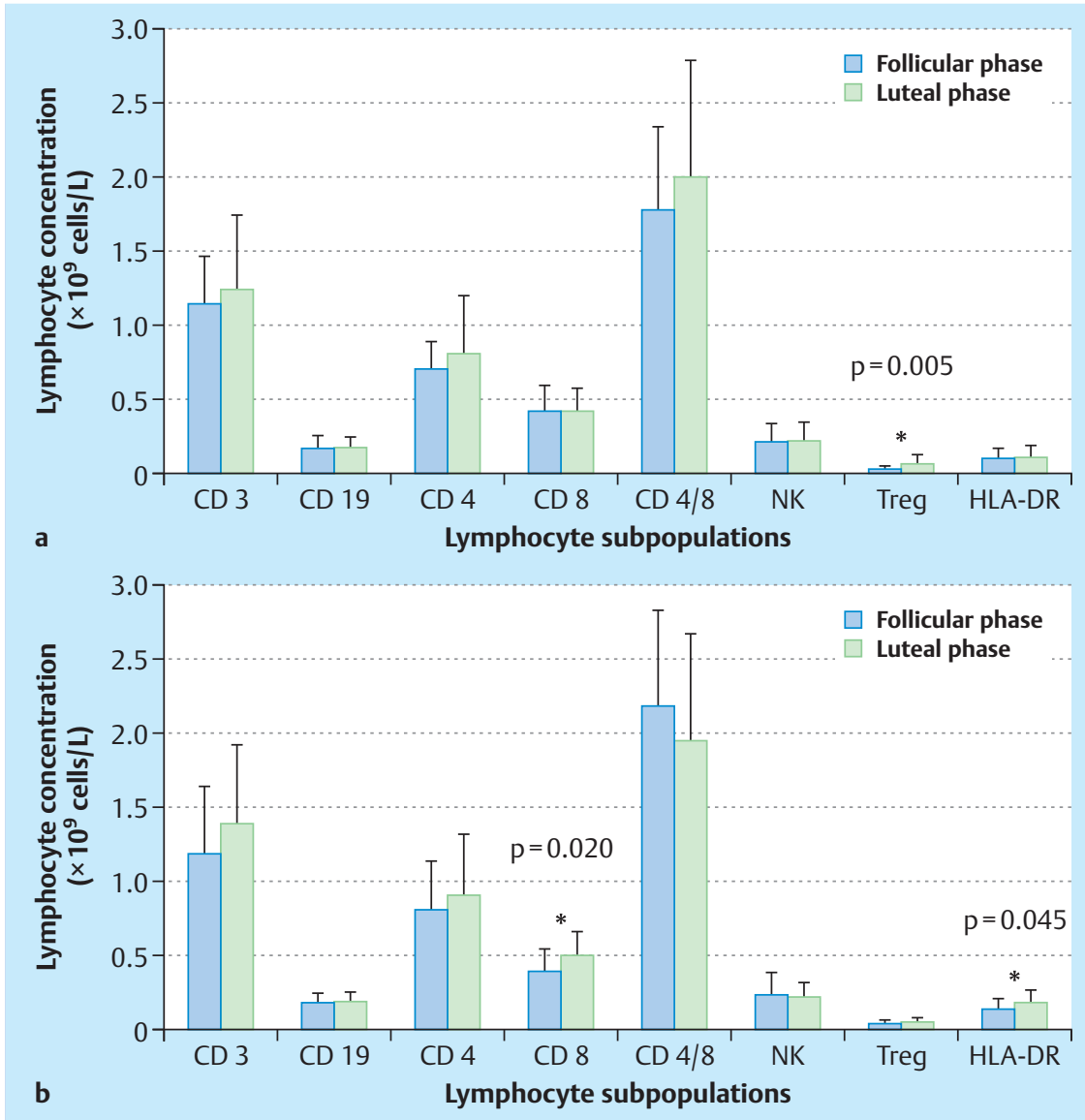

Fig. 1 a and b Peripheral blood lymphocyte subpopulations in follicular and luteal phase of menstrual cycle in women with endometriosis (a) and without endometriosis (b). Data are presented as mean \pm SD and $p$-value as analysed by unpaired t-test $\left({ }^{*} p<0.05\right)$. Lymphocyte subpopulations: T lymphocytes (CD3 $\left.3^{+}\right)$; B lymphocytes $\left(\mathrm{CD} 19^{+}\right)$; Thelper cells (CD4 $\left.{ }^{+}\right)$; cytotoxic $T$ lymphocytes $\left(\mathrm{CD}^{+}\right)$; natural killer cells (NK); regulatory T lymphocytes $\left(\mathrm{CD}^{+} / \mathrm{CD}^{2} 5^{++}\right)$; activated T cells (HLA-DR).

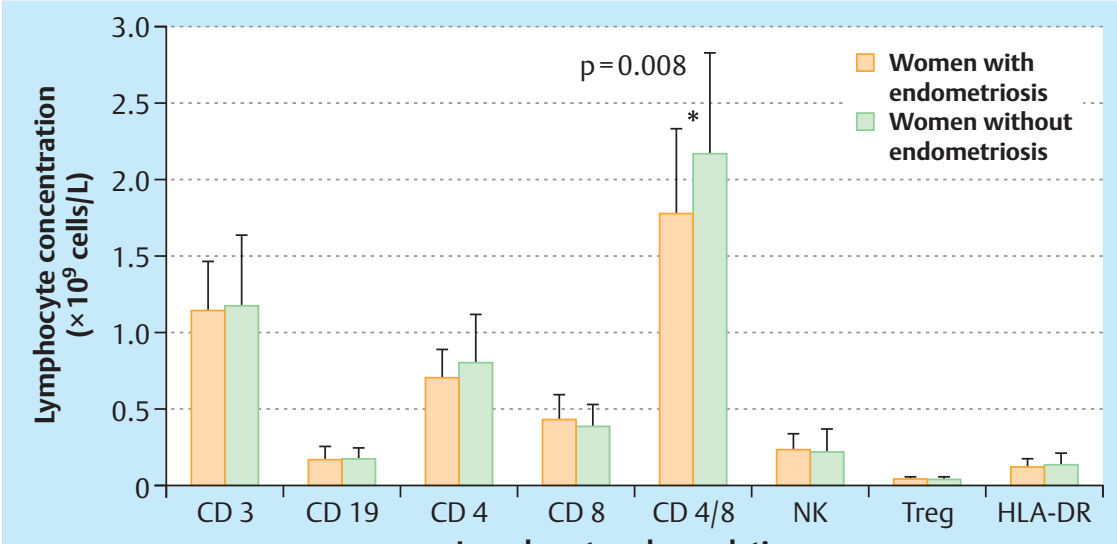

a

Lymphocyte subpopulations

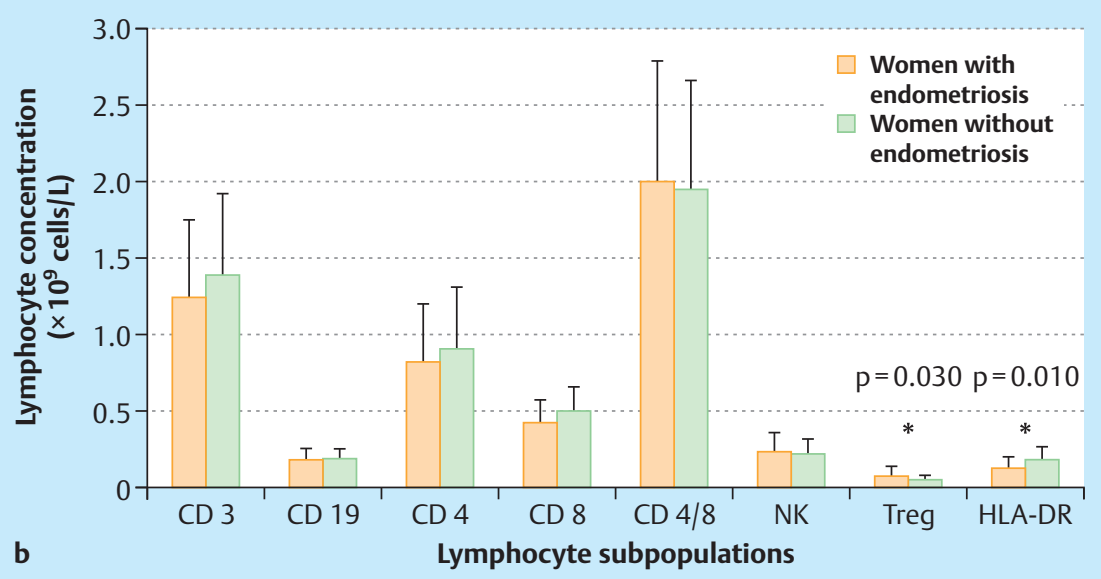

Fig. $\mathbf{2 a}$ and $\mathbf{b}$ Peripheral blood lymphocyte subpopulations in women with endometriosis and without endometriosis in follicular (a) and luteal phase of menstrual cycle (b). Data are presented as mean \pm SD and $p$-value as analysed by unpaired t-test $\left({ }^{*} p<0.05\right)$. Lymphocyte subpopulations: T lymphocytes $\left(\mathrm{CD}^{+}\right)$; B lymphocytes $\left(\mathrm{CD} 19^{+}\right)$; $T$ helper cells $\left(\mathrm{CD}^{+}\right)$; cytotoxic $\mathrm{T}$ lymphocytes $\left(\mathrm{CD}^{+}\right)$; natural killer cells (NK); regulatory T lymphocytes $\left(\mathrm{CD}^{+} / \mathrm{CD}^{2} 5^{++}\right)$; activated $\mathrm{T}$ cells (HLA-DR). 
Table 3 Cortisol and correlations with peripheral blood (PB) lymphocyte subpopulations. Lymphocyte subpopulations: T lymphocytes $\left(\mathrm{CD}^{+}\right)$; B lymphocytes $\left(\mathrm{CD} 19^{+}\right)$; $T$ helper cells $\left(\mathrm{CD} 4^{+}\right)$; cytotoxic $\mathrm{T}$ lymphocytes $\left(\mathrm{CD} 8^{+}\right)$; natural killer cells (NK); regulatory $\mathrm{T}$ lymphocytes $\left(\mathrm{CD}^{+} / \mathrm{CD}^{2} 5^{++}\right)$; activated $\mathrm{T}$ cells (HLA-DR).

\begin{tabular}{|c|c|c|}
\hline $\begin{array}{l}\text { Lymphocyte } \\
\text { subpopulations }\end{array}$ & $\begin{array}{l}\text { Cortisol correlation } \\
\text { coefficient }\end{array}$ & p-value* \\
\hline $\mathrm{CD}^{+}$ & -0.126 & 0.159 \\
\hline $\mathrm{CD} 19^{+}$ & -0.072 & 0.423 \\
\hline $\mathrm{CD}^{+}$ & -0.125 & 0.164 \\
\hline $\mathrm{CD}^{+}$ & -0.055 & 0.538 \\
\hline $\mathrm{CD} 4 / 8$ & -0.054 & 0.549 \\
\hline NK & 0.051 & 0.574 \\
\hline $\mathrm{CD}^{+} / \mathrm{CD} 25^{+}$ & -0.176 & 0.048 \\
\hline HLA-DR & -0.118 & 0.189 \\
\hline
\end{tabular}

* p-value was judged by Mann-Whitney test

In patients with endometriosis, lymphocyte-mediated cytotoxicity plays a major role in the clearance of ectopic endometrial cells. Treg cells are important for modulating immune response and function to maintain immunological homeostasis, which inhibit the development of immune diseases $[27,28]$.

Lymphocyte subpopulations and regulatory $\mathrm{T}$ cells in the peritoneal fluid of women with endometriosis have already been analyzed such as those published by Konincx et al. [29], Bedaiwy et al. [30], Mier-Cabrera et al. [31], and Rusdi et al. [32]. Rusdi et al. [32] showed that the percentage and the total number of regulatory $\mathrm{T}$ cells in peritoneal fluid did not significantly differ between patients with endometriosis and those without endometriosis. The study included 12 patients without endometriosis and 21 with endometriosis. The patients who had endometriosis were classified as having minimal-mild- or moderate-severe-stage endometriosis according to the criteria of the American Fertility Society (AFS). The endometriosis stage did not differ in terms of regulatory $T$ cells in peritoneal fluid. According to that we concluded that examination of regulatory $\mathrm{T}$ cell expression in peritoneal fluid is not informative. The study performed by Olkowska-Truchanowicz et al. [33] on regulatory T cells in peripheral blood and in the peritoneal fluid of patients with endometriosis had a study design similar to that of our study; however, that study included only subjects with ovarian endometriosis. They showed the percentage of Treg cells was significantly increased in the peritoneal fluid of women with endometriosis. The proportion of Treg cells was significantly decreased in peripheral blood. Podgaec et al. published [34] that the peritoneal fluid of women with endometriosis had a higher percentage of Treg cells in peritoneal fluid compared to women without the disease.

In this study, we report significant differences between endometriosis patients and health control subjects with respect to menstrual cycle fluctuations of PB lymphocyte concentrations. Changes in the concentration of $\mathrm{CD}^{+}$cells in control subjects are reflected by significant changes in the $\mathrm{CD} 4^{+} / \mathrm{CD}^{+}$ratio in the follicular phase between groups. These results are not in accordance with Lee's study [35] that detected similar changes in the $\mathrm{CD}^{+} / \mathrm{CD}^{+}$ratio in healthy women between phases because of the decrease of $\mathrm{CD}^{+}$cells. In his study, the $\mathrm{CD} 8^{+}$cell concentration remained constant between phases.

In patients with endometriosis, lymphocyte-mediated cytotoxicity plays a major role in the clearance of ectopic endometrial cells [36]. A constant number of $\mathrm{CD}^{+}$cells during the menstrual cycle in the $\mathrm{PB}$ in endometriosis patients may reflect absent regulation

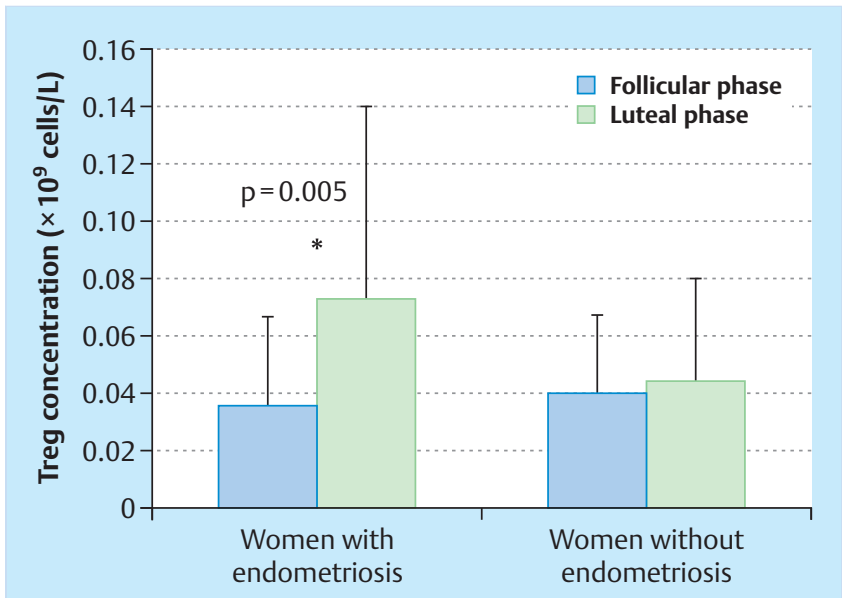

Fig. 3 Regulatory T lymphocytes (Treg) during the menstrual cycle in women with and without endometriosis in peripheral blood. Data are presented as mean \pm SD and $p$-value as analysed by unpaired $t$-test $\left({ }^{*} p<0.05\right)$

of $\mathrm{CD}^{+}$cell activity. Because most HLA-DR T cells are cytotoxic $\mathrm{CD}^{+}$cells, the lack of cycle fluctuation in activated $\mathrm{T}$ cells may also reflect absent regulation of cell cytotoxicity in endometriosis patients. In our study, we detected an increased concentration of HLA-DR T cells in the control group during the luteal phase. This fluctuation was absent in endometriosis patients. In MierCabrera's study [31], however, no changes in the concentration of HLA-DR T cells were found in women with or without endometriosis.

Because we analyzed PB lymphocyte subpopulations, we are aware that fluctuations in lymphocyte subpopulations primarily reflect a redistribution of cytotoxic cells between the blood, endometrium, and lymph nodes in different phases of the menstrual cycle. In our study, we did not detect any fluctuation of Treg cells during the menstrual cycle in healthy women in PB. Our results are consistent with Prieto and Rosenstein [20] who also did not detect any changes in Treg number in PB during the menstrual cycle in healthy, nonpregnant women of childbearing age.

In the endometrium of healthy women of reproductive age, the Treg tissue concentration linearly increases from the early to late follicular phase and decreases between the late follicular and early luteal phase of the menstrual cycle $[18,19]$. Similar Treg dynamics were described by Arruvito et al. [11] in PB, although the redistribution of lymphocyte subpopulations may not follow the same pattern in PB and tissues. In our study, the concentration of Treg cells in endometriosis patients failed to decline during the luteal phase, which may be responsible for the decreased ability of newly recruited leukocytes to initiate effective immune responses against viable endometrial segments. Berbic et al. [18, 19] observed an increase in the endometrial concentration of Treg cells during the entire luteal phase of the menstrual cycle in endometriosis patients compared with healthy controls.

In our study, we showed that the PB concentration of Treg cells in the follicular phase was similar in women with and without endometriosis, but in the luteal phase, an increase in the concentration of Treg cells in women with endometriosis, compared with healthy control subjects, was detected. Budiu et al. [37] demonstrated an increased presence of Treg cells in endometrial lesions. However, in the PB of women with endometriosis, no increase in 
Treg cell concentration above normal was detected. Basta et al. [17] did not observe any fluctuation in the percentage of Treg cells over the course of menstrual cycle in endometriosis tissue samples; additionally, the percentage of Treg cells in endometriosis patients was not statistically higher compared with healthy women who underwent curettage as an additional procedure during uterine cervix biopsy for a diagnosis of cervical intraepithelial neoplasia. The absence of menstrual cycle fluctuation of Treg tissue concentration can be linked to an immunoregulatory defect associated with the development of endometriosis.

Lima's [38] study and our study demonstrated that the serum cortisol concentrations were elevated in endometriosis patients compared with fertile women without endometriosis. The higher levels of serum cortisol in endometriosis may be associated with persistent physical or emotional stress, which may contribute to the development of the disease. An increased cortisol level inhibits PB lymphocyte activity and could favor the development of endometriosis in predisposed women. The negative correlation between concentration of Treg cells and cortisol level was shown also in our study. Higher levels of cortisol are responsible for an enhanced migration of Treg cells from PB into the tissues and reticuloendothelial system.

In studies assessing the impact of stress on cortisol levels, those levels were fluctuating within physiological range. Physiological range for serum cortisol was determined according to the endocrinological diseases, wheather the hypotalamic-pituitary-adrenal axis is over- or insufficiently active. The pathogenesis of endometriosis remains unknown but in the last years considerable evidence has pointed to immune changes that may contribute to development of disease. Several lines of evidence indicate stressrelated hormones as immunosuppressive agents [39-41]. We belive that further studies should be done in order to clarify the role of cortisol in development of endometriosis and to verify if the increase in serum cortisol concentration is one of the risk factors or just a consequence of the complex disease.

In some studies, the association of endometriosis with immune diseases, such as Hashimoto thyroiditis, systemic lupus erythematosus, Sjögren's syndrome, rheumatoid arthritis, and asthma, were analyzed $[42,43]$. Because the etiology of immune disease is closely related to Treg cell functions, a positive correlation between immunity and endometriosis would be expected [44, 45]. However, recent studies did not confirm that relationship, because they discovered that the frequency of immune diseases in women with endometriosis is equal to that in healthy subjects $[46,47]$. This is consistent with our findings ( Table 1 ).

Our present study is limited to patients with ovarian and peritoneal endometriosis. The sample size was small and further investigations are needed to reveal whether changes are similar in larger groups.

\section{Conclusions for Practice}

\section{$\nabla$}

We conclude that women with endometriosis do not exhibit fluctuations in the concentration of cytotoxic and activated PB lymphocytes during the menstrual cycle. However, a marked increase in regulatory $T$ cell concentration in the luteal phase was detected only in endometriosis patients. This can be attributed to altered immune response in patients with endometriosis and might suggest that cytotoxic cells are not sufficiently effective.

\section{Conflict of Interest}

\section{$\nabla$}

The authors declare that there is no conflict of interest.

\section{References}

1 Bulun SA. Endometriosis. New Engl J 2009; 360: 268-279

2 Pearce CL, Templeman C, Rossing MA et al. Association between endometriosis and risk of histological subtypes of ovarian cancer: a pooled analysis of case-control studies. Lancet Oncol 2012; 13: 385-394

3 Baldi A, Campioni M, Signorile PG. Endometriosis; pathogenesis, diagnosis, therapy association with cancer (Review). Oncol Rep 2008; 19 : 843-846

4 Lebovic DI, Mueller MD, Taylor RN. Immunobiology of endometriosis. Fertil Steril 2001; 75: 1-10

5 Nothnick WB. Treating endometriosis as an autoimmune disease. Fertil Steril 2001; 76: 223-231

6 Oosterlynck DJ, Cornillie FJ, Waer M et al. Women with endometriosis show a defect in natural killer activity resulting in a decreased cytotoxicity to autologous endometrium. Fertil Steril 1991; 56: 45-51

7 Lawson C, Al-Akoum M, Maheux R et al. Increased expression of interleukin-1 receptor type 1 in active endometriotic lesions. Reproduction 2007; 133: 265-274

8 Flores I, Rivera E, Ruiz LA et al. Molecular profiling of experimental endometriosis identified gene expression patterns in common with human disease. Fertil Steril 2007; 87: 1180-1199

9 Burney RO, Talbi S, Hamilton AE et al. Gene expression analysis of endometrium reveals progesterone resistance and candidate susceptibility genes in women with endometriosis. Endocrinology 2007; 148: 38143826

10 Burghaus S, Klingsiek P, Fasching PA et al. Risk factors for endometriosis in a German case-control study. Geburtsh Frauenheilk 2011; 71: 1073-1079

11 Arruvito L, Sanz M, Banham AH et al. Expansion of CD4+CD25+ and FOXP3+ regulatory T cells during the follicular phase of the menstrual cycle: implications for human reproduction. J Immunol 2007; 178: 2572-2578

12 Giatromanolaki A, Bates GJ, Koukourakis MI et al. The presence of tumor-infiltrating FOXP3+ lymphocytes correlates with intratumoral angiogenesis in endometrial cancer. Gynecol Oncol 2008; 110: 216-221

13 Nandakumar S, Miller WT, Kumaraguru U. T regulatory cells: an overview and intervention techniques to modulate allergy outcome. Clin Mol Allergy 2009; 7: 5

14 Thornton AM. T regulatory cells. Curr Biol 2005; 15: 582

15 Sakaguchi S, Yamaguchi T, Nomura T et al. Regulatory T cells and immune tolerance. Cell 2008; 133: 775-787

16 Fehervari Z, Sakaguchi S. CD4+ Tregs and immune control. J Clin Invest 2004; 114: 1209-1217

17 Basta P, Majka M, Jozwicki W et al. The frequency of CD25+CD4+ and FOXP3+ regulatory T cells in ectopic endometrium and ectopic decidua. Reprod Biol Endocrinol 2010; 8: 116

18 Berbic M, Hey-Cunningham AJ, $\mathrm{Ng} \mathrm{C}$ et al. The role of Foxp3+ regulatory T-cells in endometriosis: a potential controlling mechanism for a complex, chronic immunological condition. Hum Reprod 2010; 25: 900907

19 Berbic M, Fraser IS. Regulatory T cells and other leukocytes in the pathogenesis of endometriosis. J Reprod Immunol 2011; 88: 149-155

20 Prieto GA, Rosenstein Y. Oestradiol potentiates the suppressive function of human $\mathrm{CD} 4+\mathrm{CD} 25+$ regulatory $\mathrm{T}$ cells by promoting their proliferation. Immunology 2006; 118: 58-65

21 Fleiss JL, Tytun A, Ury HK. A simple approximation for calculating sample sizes for comparing independent proportions. Biometric 1980; 36: 343-346

22 Halis G, Mechsner S, Ebert AD. The diagnosis and treatment of deep infiltrating endometriosis. Dtsch Arztebl Int 2010; 107: 446-456

23 Ribič-Pucelj M. Endometrioza-epidemiologija, etiologija, patofiziologija in klasifikacija. In: Ribič-Pucelj M, eds. Endoskopske operacije v ginekologiji. 1st ed. Radovljica: Didakta; 2007: 163-167

24 Dejaco C, Duftner C, Schirmer M. Are regulatory T-cells linked with aging? Exp Gerontol 2006; 41: 339-345

25 Haynes $L$, Maue AC. Effects of aging on T cell function. Curr Opin Immunol 2009; 21: 414-417

26 Wang L, Xie Y, Zhu LJ et al. An association between immunosenescence and CD4(+)CD25(+) regulatory T cells: a systematic review. Biomed Environ Sci 2010; 23: 327-332 
27 Long SA, Buckner JH. CD4+FOXP3+ T regulatory cells in human autoimmunity: more than a numbers in game. J Immunol 2011; 187: 20612066

28 Pukhal'skii AL, Shmarina GV, Aleshkin VA. Regulatory T-cells: modern approaches to optimization of their numbers. Vestn Ross Akad Med Nauk 2011; 8: 24-33

29 Koninckx PR, Kennedy SH, Barlow DH. Endometriotic disease: the role of peritoneal fluid. Hum Reprod Update 1998; 4: 741-751

30 Bedaiwy MA, Falcone T. Peritoneal fluid environment in endometriosis. Clinicopathological implications. Minerva Ginecol 2003; 55: 333-345

31 Mier-Cabrera J, Jiménez-Zamudio L, García-Latorre E et al. Quantitative and qualitative peritoneal immune profiles, T-cell apoptosis and oxidative stress-associated characteristics in women with minimal and mild endometriosis. BJOG 2011; 118: 6-16

32 Rusdi G, Sumapraja K, Hadisaputra W. Distribution of regulatory T-cell $(\mathrm{Cd} 4+, \mathrm{Cd} 25+)$ in the peritoneal fluid of endometriosis patients. Ind J Obst Gynecol 2010; 34: 19-23

33 Olkowska-Truchanowicz J, Bocian K, Maksym RB et al. CD4 $4^{+} \mathrm{CD} 25^{+}$ FOXP3 $^{+}$regulatory $\mathrm{T}$ cells in peripheral blood and peritoneal fluid of patients with endometriosis. Hum Reprod 2013; 28: 119-124

34 Podgaec S, Rizzo LV, Fernandes LF et al. CD4(+) CD25(high) Foxp3(+) cells increased in the peritoneal fluid of patients with endometriosis. Am J Reprod Immunol 2012; 68: 301-308

35 Lee S, Kim J, Jang B et al. Fluctuation of peripheral blood T, B, and NK cells during a menstrual cycle of normal healthy women. J Immunol 2010; 185: 756-762

36 Viganò P, Vercellini P, Di Blasio AM et al. Deficient antiendometrium lymphocyte-mediated cytotoxicity in patients with endometriosis. Fertil Steril 1991; 56: 894-899
37 Budiu RA, Diaconu I, Chrissluis $R$ et al. A conditional mouse model for human MUC1-positive endometriosis shows the presence of antiMUC1 antibodies and Foxp3+ regulatory T cells. Dis Model Mech 2009; 2: 593-603

38 Lima AP, Moura MD, Rosa e Silva AA. Prolactin and cortisol levels in women with endometriosis. Braz J Med Biol Res 2006; 39: 1121-1127

39 Chrousos GP, Elenkov IJ. Interactions of the endocrine and immune Systems. In: DeGroot LJ, Jameson JL, eds. Endocrinology. New York: Academic Press; 2000: 571-586

40 The adrenal Glands. In: Berne RM, Levy MN, Koeppen BM, Staton BA, eds. Physiology. Missouri: Mosby; 2004: 883-919

41 Pfeifer M. Bolezni endokrinih žlez. In: Kocijančič A, Mrevlje F, Štajer D, eds. Interna Medicina. Ljubljana: Littera picta; 2005: 793-896

42 Nothnick WB. Treating endometriosis as an autoimmune disease. Fertil Steril 2001; 76: 223-231

43 Sinaii N, Cleary SD, Ballweg ML et al. High rates of autoimmune and endocrine disorders, fibromyalgia, chronic fatigue syndrome and atopic diseases among women with endometriosis: a survey analysis. Hum Reprod 2002; 17: 2715-2724

44 Eisenberg $V H$, Zolti $M$, Soriano $D$. Is there an association between autoimmunity and endometriosis? Autoimmun Rev 2012; 11: 806-814

45 Matarese G, De Placido G, Nikas Y et al. Pathogenesis of endometriosis: natural immunity dysfunction or autoimmune disease? Trends Mol Med 2003; 9: 223-228

46 Petta CA, Arruda MS, Zantut-Wittmann DE et al. Thyroid autoimmunity and thyroid dysfunction in women with endometriosis. Hum Reprod 2007; 22: 2693-2697

47 Matorras R, Ocerin I, Unamuno M et al. Prevalence of endometriosis in women with systemic lupus erythematosus and Sjögren's syndrome. Lupus 2007; 16: 736-740 